September 2004

\title{
The Interdependence of Social Identification and Learning
}

Stanton Wortham

University of Pennsylvania, stanton.wortham@bc.edu

Follow this and additional works at: https://repository.upenn.edu/gse_pubs

\section{Recommended Citation}

Wortham, S. (2004). The Interdependence of Social Identification and Learning. Retrieved from https://repository.upenn.edu/gse_pubs/75

Postprint version. Published in American Educational Research Journal, Volume 41, Issue 3, Fall 2004, pages 715-750.

This paper is posted at ScholarlyCommons. https://repository.upenn.edu/gse_pubs/75

For more information, please contact repository@pobox.upenn.edu. 


\title{
The Interdependence of Social Identification and Learning
}

\begin{abstract}
When students and teachers discuss subject matter, at least two processes generally occur: Students and teachers become socially identified as recognizable types of people, and students learn subject matter. This article contributes to recent work on how social identification and learning systematically interrelate by describing one complex way in which these two processes can partly constitute each other. The article analyzes data from across an academic year in a ninth-grade classroom, exploring how one student developed a social identity through the same conversations in which students learned aspects of the curriculum.
\end{abstract}

\section{Keywords}

learning, social identity, situated cognition, experience-near teaching

\section{Comments}

Postprint version. Published in American Educational Research Journal, Volume 41, Issue 3, Fall 2004, pages 715-750. 


\section{The Interdependence of Social Identification and Learning}

Stanton Wortham

University of Pennsylvania

Keywords: learning, social identity, situated cognition, experience-near teaching

Stanton Wortham is Professor in the Educational Leadership Division, Graduate School of

Education, University of Pennsylvania, 3700 Walnut Street, Philadelphia PA 19104-6216; email stantonw@gse.upenn.edu. His research applies techniques from linguistic anthropology to study how interactional positioning and social identity development interconnect with the cognitive functions of classroom, media and autobiographical discourse. 


\begin{abstract}
When students and teachers discuss subject matter, at least two processes generally occur: students and teachers get socially identified as recognizable types of people; and students learn subject matter. This article contributes to recent work on how social identification and learning systematically interrelate, by describing one complex way in which these two processes can partly constitute each other. The article analyzes data from across an academic year in one ninth grade classroom, exploring how one student developed a social identity through the same conversations in which students learned aspects of the curriculum.
\end{abstract}




\section{The Interdependence of Social Identification and Learning}

Over the past several decades, research in the anthropology and sociology of education has described how students' diverse social identities both influence and are shaped by schooling (e.g., Cazden, John \& Hymes, 1972; Mehan, Villanueva, Hubbard, Lintz, \& Okamoto, 1996; Varenne \& McDermott, 1998). At the same time, research in cognitive science has described how students learn the disciplinary knowledge that makes up the curriculum (e.g., Leinhardt, 2000; Sinatra, Beck \& McKeown, 1992; Wineburg, 2001). Although these two broad traditions have taught us much about social identification and learning in school, they have not often been brought together in systematic and productive ways.

Pioneers like Bateson (1972) and Vygotsky (1934/1987) attended to both social identification and learning long ago, but only in the last decade or two has a large group of researchers attended to connections between these two processes. Much of this recent research represents what Packer (2001) calls an “ontological” approach to learning (cf. also Dreier, 2003; Lave, 1993; Wenger, 1998). According to an ontological approach, learning changes not just what the learner knows (which would be simply “epistemological”) but also who the learner is. To learn is to take up a new practice, to change one's position in a community. Thus learning can change identity and the self. When children learn to read, or to do arithmetic, or to understand evolution, they become people who participate in new social activities like reading the newspaper or shopping. Schools, then, are "crucibles wherein children are transformed" (Packer, 2001, p.1).

According to an ontological account, learning is by definition intertwined with social identification. "Because learning transforms who we are and what we can do, it is an experience of identity” (Wenger, 1998, p.215). This article describes a type of intertwining between social 
identification and learning that happens in classrooms. My account of this phenomenon fits under the umbrella of ontological approaches to learning, because I argue that the two processes are inextricable and that students’ learning can change who they are. Unlike many other ontological approaches, however, I describe a specific, complex mechanism through which social identification and learning can intertwine. I provide a conceptual account of one way in which social identification and learning can become deeply interrelated and present empirical evidence that supports this account.

The empirical analyses follow one student across the year in a ninth grade English and history classroom, showing both how he develops aspects of his identity as teachers and students use concepts from the curriculum to identify him, and how students learn in part because this student gets identified in ways that illuminate the curriculum. These students and teachers use curricular categories as tools to help them identify students, and they use categories of identity as tools to help them understand the curriculum. The analysis shows how local versions of these categories develop in the classroom across the academic year, and how these local categories simultaneously contribute to identifying the student and to helping students learn about a curricular theme. When categories of identity and curricular categories intertwine in this way, across many classroom discussions, social identification and learning can become inextricable. Together with other recent studies of “ontological” learning, this study suggests that accounts of social identification and learning will be incomplete if they do not attend to both processes.

\section{Social Identification in the Classroom}

Social identification is the process through which individuals and groups get identified as instances of publicly recognized categories of people. This process requires two primary 
components: social categories of identity that circulate through time and space, and the characteristics or behavior of individuals that gets interpreted with reference to those categories (Agha, 2003; Bourdieu, 1984; Urban, 2001). In order to be socially identified, a person must exhibit some characteristic or behavior—say, an affinity for programming computers and playing computer fantasy games — that can be taken as a sign of a recognizable social type—say, being a "nerd." For this behavior to count as a sign of that social identity, interpreters must presuppose socially circulating categories of identity that recognize "nerds" as a social type, and they must apply these categories of identity to construe the target person’s computer programming and fantasy gaming.

In most contexts, more than one set of categories might potentially frame any behavior, such that a focal behavior could be a sign of different social identities (Goffman, 1974; Silverstein, 1992). For instance, the emergence of dot.com millionaires in the late 1990's provided another category of identity for construing behaviors like computer programming and fantasy gaming. These behaviors could still identify someone as a “nerd," but they might also have identified him or her as a potential millionaire with whom one would want to go into business. Analyses of social identification must show how behaviors come to count as signs of particular identities, from among the various available identities that might be getting signaled, as the focal behaviors get consistently framed by participants in terms of some specific categories of identity.

The analysis of social identification requires attention to several "timescales” across which signs and categories of identity circulate (Cole, 1996; Lemke, 2000). There are "socialhistorical” patterns, which develop over decades and centuries. The categories that define available social identities, and the behaviors that get taken as signs of identity, change over 
historical time. There are “ontogenetic” patterns, which develop over months and years. Particular students get socially identified over biographical time, drawing on but also developing sometimes-unique configurations of social-historical categories. There are "local” patterns, which develop over days, months and years. Sometimes members of a small group-like teachers and students in a classroom over an academic year-use context-specific categories of identity to make sense of others' actions. There are “microgenetic” patterns, which develop over seconds and minutes. Participants in an interaction get identified as they treat each others' behaviors as signs of identity within particular events.

Students bring some aspects of their social identity with them to school, based on socialhistorical and ontogenetic categories of identity that circulate into the school—e.g., being an “athlete,” being “good looking,” being a "good student” and so on. Locally, in any classroom over an academic year, particular versions of social-historical categories get used to construe signs of identity among teachers and students. Being an "athlete” or a "good student” means different things in different classrooms and among different groups. In order to analyze social identification in school we must study how particular versions of social-historical categories get contextualized and circulate locally, as these categories get used to identify individuals in particular classroom contexts and in particular events.

Individuals get identified when, across several events, categories of identity are used to frame their behavior as being the kind of thing a recognizable type of person would do. These categories of identity are drawn both from social-historical and from local timescales. This article describes how, in one classroom across an academic year, teachers and students established local categories of identity, drawing on but modifying social-historical categories. Then it describes how teachers and students used the local categories consistently to identify one 
student. As shown in the next section, these local categories of identity also helped students learn the curriculum.

The data reported in this article come from one academic year in a ninth grade urban U.S. English and history class. The class was taught jointly by an English teacher and a history teacher, Mrs. Bailey and Mr. Smith, who combined their classes into an eighty minute block twice a week. (All names are pseudonyms, and some identifying details have been changed.) They ran these eighty minute classes as Paideia or great books “seminars” (Adler, 1982), discussions in which the teachers encouraged students to articulate and defend their interpretations of texts. There were nineteen students in the class, approximately two-thirds African American and two-thirds girls. Wortham (1994) provides detailed descriptions of individual teachers and students and statistical overviews of classroom discussions. I observed this class about fifty times over one academic year and recorded 28 of these classes. Data include fieldnotes, audiorecordings, and interviews with teachers and students. To gather evidence about the focal student's social identity, I searched the entire corpus for explicit statements about this student and for events in which he was socially identified. I analyzed the data using established methods of discourse analysis through which an analyst can uncover systematic ways in which speech helps identify individuals (Fairclough, 2003; Gee, 1999; Wortham, 2001b).

Maurice was a fourteen year old African American boy who entered Mrs. Bailey and Mr. Smith’s class at the beginning of ninth grade. Like most of his fellow students, Maurice had scored in the third quartile on the citywide test for eighth graders. Also like many of his peers, he was verbally skilled and seemed more intelligent than his test scores indicated. Maurice was relatively popular with his fellow students. He joked and had playful wrestling matches with his 
male friends before and after class, and in the halls. He tried to sit with at least one of the other boys during class, and he would sometimes talk to them surreptitiously during lessons. Maurice was physically larger than average, and he was a reserve on the football team. He was attractive, and many of the girls flirted with him throughout the year. He was interested in the girls as well, and he teased, chatted and occasionally fought with them both inside and outside of the classroom.

From the start of the year Maurice participated actively in class discussions. He was regularly one of the half dozen students most actively contributing to discussion, and he made intelligent contributions to most of the classes he attended. From September through December, both teachers and students identified Maurice as a valued participant. When he answered a question or made an argument, teachers and other students accepted his contributions without undue skepticism or teasing. Early in the year neither the teachers nor the students treated him any differently than they did the core group of six to eight vocal female students who dominated class discussion all year.

After being just another good student early in the year, however, Maurice’s identity became more complicated around December. In this classroom, sometime in November, teachers and students began to presuppose that girls and boys are different. Mrs. Bailey both explicitly and implicitly communicated that girls are more promising, saying that they cooperate more with the teachers, are more intelligent, and will more likely succeed in later life. She said that boys, in contrast, more often resist classroom expectations, are less intelligent, and will likely not succeed in later life. On November 30, for instance, she said "Okay, that's one meaning of discrimination. I look and I see differences...I see that Katina is a girl and William is a boy and I discriminate against William because he's a boy and girls are much easier to deal 
with." Taken by itself, this may simply have been an offhand comment, or it may have been ironic. But Mrs. Bailey and the girls repeated this gendered characterization many times. The girls also regularly dismissed boys’ contributions. Although any single instance in which teachers and students described or treated girls as promising and boys as unpromising may not have been serious, the recurrence of this pattern suggests that Mrs. Bailey and the girls did treat the boys as academically unpromising.

The following segments provide further evidence that Mrs. Bailey and the girls systematically identified the boys as unpromising. Right before the following segment, from a discussion on January 25, Maurice has accused Gary of interrupting him. Mrs. Bailey and several girls then treat Gary in a way that they typically treat the boys (Wortham, 2003; in press). (Transcription conventions and a list of abbreviated participant names are in the Appendices).

MRC: [every time I say something you got something to say about it STS: [4 seconds of yelling]

110 FST: I'm sick of it. he get on my nerves.

STS: [4 seconds of yelling]

FST: he criticizing, but he don’t say anything. because [[4 unintelligible syllables]

T/B: ah [I think that maybe, ladies. I think then that

115 maybe because I'm not always picking up what Gary's doing over there, he kind of makes himself invisible to some extent $=$ FST: (hh) 
T/B: =if, you know, if he is saying something that

120 you would like him to share with the group or you think=

FST: ah

T/B: =he needs to share with the group, either because it will contribute to the conversation=

125 FST: oh I don't know

T/B: =or because it will embarrass him, maybe we should get it out, okay?

At lines 110 and 112, two girls characterize Gary as making unwarranted and unproductive criticisms. This characterization is not necessarily gendered yet, because Maurice has made a similar criticism at line 107. But at lines 116-117, Mrs. Bailey says that Gary "makes himself invisible.” This fits with the habitual actions that have developed over the year, in which boys sit in the back of the room and generally refuse to say anything while the teachers and the girls run the discussion.

More telling than what Mrs. Bailey and the girls say about Gary is how they treat him. Although Maurice referred to Gary as "you” in line 108, treating him as an addressee, the girls and Mrs. Bailey refer to Gary in the third person throughout the segment. They talk about him, not to him. Mrs. Bailey further excludes Gary when she presents the girls as controlling the conversation. Mrs. Bailey casts girls in a teacher-like role, empowering them to judge whether Gary should share something (at lines 119-127). At line 126 she even suggests that they might tease Gary, saying that the girls could ask him to share something with the group in order to “embarrass” him. Mrs. Bailey often uses teasing in a pedagogically skillful way, to involve 
students or to defuse a tense situation. But sometimes she joins the girls in teasing one or more of the boys, as she recommends for Gary here.

This example illustrates how Mrs. Bailey and the girls sometimes exclude the boys from the classroom conversation, positioning them as third person objects of discussion and as legitimate targets of the girls’ teasing. This pattern recurs in the following discussion, from February 18. Mrs. Bailey and the students are discussing the Odyssey, specifically Odysseus’ encounter with the Sirens. The Sirens were female creatures who lured seafaring men to their island with enchanting songs. Upon arriving, however, men discovered that the Sirens were in fact hideous carnivores who wanted to eat them.

T/B: okay, women are dangerous. what do we do?

STS: [laughter]

30 T/B: what do we do? William, what do women $\underline{\text { do }}$ that's dangerous?

FST: ${ }^{\circ}$ we’re waiting ${ }^{\circ}$

T/B: Maurice, what do women do that's dangerous?

35 FST: when you're surrounded by them you better watch out. [laughter from female students and T/B] T/B: what do the girls in this room $\underline{\text { do }}$ to create a danger for you?

Mrs. Bailey creates an analogy between the Sirens and the girls in the classroom. She gives this analogy in order to help students understand how Homer conceives of women as dangerous and 
distracting to men, by discussing how these girls might distract these boys. The girls' laughter at lines 29 and 36 suggests that the girls and Mrs. Bailey are teasing the boys, as well as discussing this example for academic purposes. Mrs. Bailey might also be using this teasing to entice the boys into participating in the discussion. Because of sociohistorical patterns that she did not create (Anderson, 1999; Ferguson, 2000), the teacher has several unresponsive boys in her classroom, and she tries repeatedly to help them by connecting the subject matter to their experiences. Mrs. Bailey and the girls are clearly having fun here, but the teacher is also trying to involve the students in academically productive discussion.

Classroom discourse like this often has multiple functions. In addition to being funny, and in addition to being an overture to involve the boys in discussion, Mrs. Bailey and the girls also reinforce a recurring local identification of the boys as academically unpromising. Mrs. Bailey and the girls often tease or talk about the boys, while the boys refuse to participate and silently endure this treatment. As they continue discussing the Sirens, Mrs. Bailey and the girls respond to the boys' silence by again characterizing the boys as unpromising.

T/B: I want your opinion. what, what might happen to you, Maurice? (10.0) Maurice, is this thing in this classroom full of women a distraction? [female laughter] would you do better in a classroom full of boys? (4.0)

$50 \quad$ MRC: ${ }^{\circ} \mathrm{I}$ don’t know ${ }^{\circ}$

T/B: Maurice, I'm asking you a question.

MRC: I don't know.

T/B: you don't know.

JAS: you would because they are able to take [4 
55 unintelligible syllables] stupid things because if more boys than girls

T/B: oh the place would get stupider. [laughter from female students]

T/B: that's how boys are, they're kind of stupid. maybe, maybe

60 the boys in this room are a little bit [2 unintelligible syllables]. okay, ahh (6.0) I am going to have to ask this question to the girls because the boys aren't very forthcoming. anybody in here ever have a crush on somebody?

At lines 54-56, Jasmine suggests that the boys typically say stupid things in class. The teacher picks this up at lines 57-59. She may still be teasing here when she calls the boys stupid. But she then directs her instruction exclusively to the girls after line 61, thereby enacting the difference between promising girls and unpromising boys-i.e., presupposing that it is not worth teaching the boys because they do not respond anyway. Because this continues the recurring treatment of the boys as academically unpromising, the teacher and girls are most likely not just teasing here.

These and similar incidents from December through June reinforced the local identification of girls as promising and boys as unpromising. My interpretation of Mrs. Bailey and the girls' consistent behavior toward the boys becomes more plausible, given the sociohistorical realities of gender and school success in the contemporary United States. Over the last several decades, girls have overtaken boys in many areas. Girls get better grades, outperform boys on standardized tests, drop out less, enroll in and graduate from college at higher rates (Sum, et al., 2003). Sexism persists in schools, and it disadvantages girls in various 
ways (Brown \& Gilligan, 1992; Holland \& Eisenhart, 1990; Sadker \& Sadker, 1995), but boys face increasing challenges of their own (Newkirk, 2002), and their academic performance shows it. Popular culture also circulates stereotypes of boys as not only less skilled in school but also as more susceptible to violence and other anti-social behavior, as well as the stereotype that school success is unmasculine (Pottorff, Phelps-Zientarski \& Skovera, 1996). Ethnographic studies have shown how such stereotypes filter down to teachers and students, such that they believe boys are less likely to work hard and succeed in school (Honora, 2003; Wortham, 2001c).

This sociohistorical model of boys - as disinterested in school, prone to anti-social behavior and less likely to succeed in school and life-is not only about gender, because it is disproportionately applied to African American boys (Jordan \& Cooper, 2003; Spencer, 1999). Ferguson (2000) describes how black boys are disproportionately disciplined in school, labeled as "at risk" and as "failures." She argues that school rules "seem to be specifically designed to control, manage and channel the 'natural' behavior of boys [and black boys in particular], who are said to be more physical, aggressive, sexual. Girls are believed to be more naturally agreeable, tractable, and able to tolerate the controlled atmosphere” (p. 42). This model of black boys at school fits with broader stereotypes of black men as aggressive, as overly concerned with respect, as violent and as irresponsible fathers (Anderson, 1999; Gadsden, Wortham \& Turner, 2003; Nightingale, 1993). Maurice and the other black boys in Mrs. Bailey and Mr. Smith’s class are at risk of being identified with respect to this model of unpromising boys just because they are black and male in contemporary America. So even though Mrs. Bailey and the girls sometimes appear simply to be teasing the boys, I argue that they are also-tacitly, and perhaps unintentionally_characterizing the boys as academically unpromising. 
More than any other presupposed category of identity, gender became relevant to the social identification of students in this classroom. By the middle of the year, Mrs. Bailey and the girls routinely identified the boys as unpromising and the girls as promising. These presuppositions about gender became robust local categories of identity, available to frame particular students' identities. This gender stereotype was unpleasant for the boys, but they sat in the back of the room and silently endured it. As described by Foley (1996), Moje (2000), Willis (2001) and others, such silence need not be interpreted negatively, as lack of intelligence or as a refusal to act. Instead, silence and resistance can be sensible attempts to claim an alternative identity in a hostile setting.

Maurice, however, was in a more complex position than the other, silent boys. He was the one male student who did not behave as if he fit the gender stereotype, because he actively and constructively participated in class discussions. At the same time, however, he wanted to be respected by the other boys. Anderson (1999), Ferguson (2000) and Fordham (1996) have described this predicament, in which some black students face a choice between school and peer expectations. In this classroom, with its robust local expectations about gender identity, Maurice increasingly got caught between being a good student and being a respected male.

By December, several vocal girls were making Maurice’s predicament salient by challenging his contributions on a regular basis. In a discussion of civil war on December 17, for instance, the class was defining "civil war," and the girls jumped in quickly when it looked as if Maurice was about to make a mistake.

T/B: what kind of war do you get family on opposite sides? (2.0) civil war. what's a civil war?

FST: ${ }^{\circ} \mathrm{a} w \mathrm{a}\left[\mathrm{r}^{\circ}\right.$ 
FST: $\quad[$ a war

40 MRC: [a war against- one country against-

FST: $\underline{\text { no }}$

FST: no

FSTs: [2 seconds of overlapping chatter]

T/B: okay, a war within the country. a war with- shhh

45 FST: [6 unintelligible syllables]

T/B: a wa:r within the country. so brother fights against

brother. neighbor fights against neighbor. is there any

outside invasion going on here, am I protecting my home

against a bunch of foreigners?

50 MRC: $\underline{\text { no }}$

FST: $\underline{\text { no }}$

FST: no

At line 41 a female student jumps in, saying “no” with a distinctive mid-high-mid intonation contour (the same as one would find with “duh,” perhaps meaning 'how could you be so stupid as to say that'). Another student echoes her at line 42. Maurice had only begun to make an error, and it was not a major one, but the girls quickly jump on him. At line 50 Maurice says “no” himself, perhaps attempting to preempt the girls’ criticism. But the same girls repeat "no” at lines 51 and 52, with the same intonation contour, perhaps to remind everyone of Maurice’s earlier mistake.

In many examples like this, from December through June, several girls attempted to identify Maurice as an unpromising male student, taking advantage of the local categories of 
promising girls and unpromising boys. Nonetheless, Maurice did not become a prototypical unpromising boy, because he continued to contribute in ways the teachers explicitly recognized as valuable. Mrs. Bailey sometimes joined the girls in teasing him, but the teachers nonetheless continued to value his contributions and to identify him as a good student. Maurice sometimes had to struggle against the girls' teasing, but he often managed both to participate successfully in class and to retain his standing as one of the boys.

Maurice’s social identity in this classroom, then, was established over several months. He began as just another good student, participating unproblematically in class, and also as a respected male. But by December Mrs. Bailey and the girls established robust local gendered categories of identity, “promising girls” and “unpromising boys.” They drew these categories of identity from longer timescale sociohistorical processes that involve gender and race. But there were many other potentially relevant sociohistorical categories of identity that did not become salient in this classroom, while the category of unpromising boys was both explicitly articulated and tacitly used to frame male students' behavior. Maurice struggled against having this local category of identity applied to him, trying to maintain his earlier identity as both a good student and a respected boy. Sometimes he managed this, but the vocal girls often forced him to confront the tension between the two aspects of his identity. Given sociohistorical facts about race, gender and school success, it can be hard to maintain a position as both a good student and a respected black male. In this classroom, with its robust local assumptions about gender, Maurice had to work hard to maintain both aspects of his identity. The next section shows that, while Maurice and other participants were working on his social identity, they were also engaging with the curriculum. The subsequent section shows how the processes of social identification and learning intertwined. 


\section{Learning in the Classroom}

Some recent theories of cognition have moved away from the lone thinker. Instead of individuals developing their own representations of reality, many now conceptualize knowledge as created and justified in collective practice. "Situated" and "sociocultural" accounts of cognition describe how cognitive accomplishments result from processes that can include mental, social, physical and symbolic components (Greeno, 1997; Latour, 1993; Rogoff, 1998; Wertsch, 1998). Such accounts describe how successful cognition depends on multi-component systems that include tools and artifacts, the physical layout of settings, the distribution of knowledge among people, and other components (Goodwin, 1995; Hutchins, 1995; Lave, 1988; Lemke, 2000; Wortham, 2001a). Lave (1993) and Wertsch (1998) propose that the systems that facilitate cognition and learning always include at least three types of components: the person or "intramental" structures and processes, the activity or "intermental" structures and processes, which involve tools and other participants in the activity, and the situation or social-historical structures and processes.

Learning thus involves not just the development of representations within an individual, but the integration of intramental components with intermental and social-historical ones, in a system that crosses levels. Reading, for instance, depends on neurological and mental capacities to distinguish letters, words, clauses, and textual patterns, on situational cues in the text and the surrounding activity, often on help or cues from others engaged in a task, on cultural practices that both construe and integrate reading in particular ways, and on social-historical processes that identify different kinds of people as readers, different kinds of texts as worth reading, and different strategies as more and less sophisticated. To conceptualize learning to read as merely creating new mental representations or skills would be to misperceive the relations among 
intramental, intermental and social components of a system-i.e., to misperceive a multicomponent, dynamic process as a homogeneous one. Learning does involve structures and processes inside an individual's mind, but it always involves more than this.

Dreier (2003) argues, furthermore, that we must not imagine learning as occurring and getting completed in a single event. People do not generally construct or internalize cognitive models in single events, then transfer these to solve problems in new contexts (cf. also Lave, 1988; 1993). As Cole (1996) and Rogoff (1998) put it, an event is not a self-contained task for the use of established knowledge. Performance in each event involves a heterogeneous set of resources from different timescales. As people move from one event to another, they are constrained by and adopt different sets of resources in new settings. There are, of course, consistencies from one event to the next. Most importantly, people can systematically change the resources they use and change how they react to affordances that recur across events. From a sociocultural point of view, learning occurs across trajectories of events as people deploy cognitive resources in changing ways. Learning is "change in the relations between persons and their situation in a way that allows for the accomplishment of new activities” (McDermott, 1997, p.127).

To study learning in this sense, we must follow people across contexts and observe how they pursue new possibilities in new contexts, how they take what Dreier (2000) calls “new angles.” A new angle is a different way of thinking or acting in a given context, which allows participants to pursue previously unavailable alternatives. When people pursue new angles, we should not immediately posit individual skills or representations as the primary source of the change. Instead, we must explore the various resources present in events along the trajectory of learning events, how the configurations of resources change from event to event, and whether 
some cross-timescale configurations either change or recur so as to facilitate the new angles people adopt.

Although we cannot generally explain learning by proposing a fully formed representation that individuals transfer from one context to the next, it does not follow that every cognitive accomplishment is situation-specific (Dreier, 2003). We must describe the changing configurations of resources across contexts that facilitate learning. These resources will often include representations and skills that individuals develop and bring with them, but such intramental resources generally constitute only some of the resources through which people solve problems and learn.

Mrs. Bailey and Mr. Smith, Maurice’s teachers, had pedagogical goals that can be construed according to a sociocultural account of learning. These teachers intended to socialize students into the intellectual practice of rational argument, as that practice is envisioned by Adler (1982) and others in the Paideia or "great books" tradition (Wortham, 1995; 2001a). This requires that students learn how to develop their own arguments and how to use evidence to support those arguments. Students were expected to read texts carefully, to ask questions that engage with complex issues raised by the texts, to understand and evaluate others' arguments about important issues, and to construct and defend their own arguments about these issues.

The teachers wanted students to apply these skills while engaging with what they and great books pedagogy call “issues of enduring human concern.” For instance, Mrs. Bailey articulated one such issue on January 24:

And the principle that I find extremely interesting in here is this idea that the state is prior to the individual. The state is prior to the individual. If you would take a look on the second page, the first column, the beginning of the second paragraph. Further, the state is 
by nature clearly prior to the family and to the individual, since the whole is of necessity prior to the part. And I am asking my question here is, do you agree that the state is prior to the individual, or do you even know what that means maybe?

Many societies have faced the question of how to balance individual desires with collective needs. Some societies tend to sacrifice individual freedoms for the good of the whole, while others downplay the needs of the group and focus on the rights of the individual. In developing their curriculum, the teachers selected from among the many texts that have argued for some position on this question of enduring concern. For instance, they had students read arguments from Aristotle that the state is necessarily prior to the individual, extreme collectivist arguments from Plutarch's account of Lycurgus, and extreme individualist arguments from Ayn Rand. The teachers wanted students to recognize this larger debate between collectivism and individualism and to understand some of the classic positions taken on it.

In order to learn as the teachers intended, students had to use resources from various timescales. The curriculum drew on social-historical patterns, ones that take place over centuries and decades. Intellectual positions have developed historically in various traditions, and the curriculum in this classroom drew on exemplars from various times and places. In discussing the curriculum, teachers and students adopted centuries-old practices and tools for constructing arguments and reasoning about sociopolitical topics. At a local timescale, over the academic year in this classroom, local versions of these larger intellectual positions became themes that teachers and students recognized. In addition to local versions of curricular themes, teachers and students also built group discussions, creating intermental scaffolds of ideas and evidence that facilitated individual arguments. At the timescale of events, discussions both drew on and contextualized themes and positions from the curriculum and the society. Students learned what 
they did by participating in actual classroom discussions. This article focuses on one local resource that teachers and students developed over a month or two-a particular construal of the concept of "outcast” that they used while addressing the curricular theme of collectivism/individualism. Students and teachers used this local concept to develop their arguments about collectivism and individualism, and this local concept became an important resource in the cognitive systems that constituted students' learning. As described in the next section, this same local concept also became integral to the social identification of Maurice.

In order to investigate the learning that occurred in Mrs. Bailey and Mr. Smith’s classroom, I reviewed the entire corpus of recorded classes. I identified explicit statements by students about two central curricular themes discussed from January through May, as well as more complex configurations of ideas and arguments that students developed around these themes. I traced emerging local versions of the two curricular themes, by following students' and teachers' discussions across classes. This yielded descriptions of specific construals that teachers and students made of the themes, across weeks or months. Then I identified and analyzed classroom conversations in which students applied concepts from these curricular themes to particular texts, conversations that showed students were able to apply these themes and formulate arguments about them. In doing these analyses, I applied discourse analytic techniques for identifying concepts and arguments in classroom talk (Castanheira, Crawford, Dixon \& Green, 2000; Cazden, 1988; Rex \& McEachen, 1999). Because this study was not designed to gather evidence of learning, I did not collect other potential indicators of learning, like assignments, interviews or cognitive tasks. I nonetheless have extensive evidence of students participating in the practice of reasoned argumentation, and this evidence strongly 
suggests that categories of identity intertwined with and facilitated students' learning of the curriculum.

In January and February, Mrs. Bailey, Mr. Smith and their students focused on the curricular theme of collectivism and individualism. By this point in the year, most of the vocal students could reason about a text according to the Paideia or great books approach—identifying a relevant curricular theme as central to a new text, locating the author's argument with respect to other classic positions on the theme, offering their own arguments for positions that differed from the author's, and supporting their arguments with evidence from this and other texts and from their own lives.

Students demonstrate some of these skills in the following excerpt, from January 25. On this day they discussed Ayn Rand's Anthem. This book advocates an extremely individualistic society in which people do not have to contribute to the common good, in which we "do not owe anything to our brothers.” Students object to this, arguing that members of a society should have collective responsibility for others. ("They” in line 514 refers to members of Rand's imagined individualist society, and “he” in line 522 refers to Rand’s protagonist.) 
KTN: well, if we do, if we do owe our

brothers and stuff, things would probably be different. they

515 probably don't have to do that if they don't want to.

FST: what?

T/B: okay, they don't have to do that if they don't want to, they

don't have to pay taxes and things like that.

TYI: they don't have to do nothing if they don't want to do

520 it.

T/B: okay.

FST: then he won't take them.

MRC: if they didn't, they would have a poor society. all these bu:ms on the street, people that can't afford to feed their babies

525 and people dying constantly.

FST: right.

T/B: okay, so he's creating a society that you don't think is going to be a good society =]

MRC: ] right.

530 T/B: =because you need to , have it built in that you help people.

MRC: right

T/B: okay, everyone can't take care of themselves, is that what you're telling me?

535 CAN: right, you gonna need somebody to do different things. 
you can't do everything all by yourself.

MRC: right.

FST: just like farming. we don't know how to farm, so other people farm for us and then we- we pay for them to bring food,

540 to bring the food over. some people know how to $\underline{\text { umm, you }}$ know, make money. we don't know how to make money. T/B: well, take the farmers. the farmers aren't doing a real efficient jo:b, and as a result we have all these farm subsidies. we give farmers money to keep them operating. is that what

545 we should do?

CAN: yeah, it's helping us eat.

T/B: it's helping us eat, so we're doing something even though they're not doing, perhaps some would say not a very good job? therefore

550 CAN: I think in order to be a farmer, that's kind of dangerous job for the people to do. other people, they live by themselves, other people. they have to have survival and-

FST: Mrs. Bailey

T/B: yes?

555 FST: also our taxes help us to have funds and scholarships for people who can't go to school, that can't afford it for free clinic for people that's poor and need a checkup. 
In this passage, students display understanding of the particular text and discuss the curricular theme it raises. Their comments at lines 513-515 and 519-520, and the fact that they mount a counter-argument, show that at least some of the students understand Rand's claim that individuals should pursue their own self-interest. (Rand rejects altruism, arguing that the only moral stance for humans is rational pursuit of self-interest). Students also engage in the kind of reasoned discussion that the teachers hope for. In this passage students connect their reading of Rand to earlier discussions about individualism and collectivism, they articulate a position on this curricular theme, and they defend their position by citing examples from their own experience.

The students reason about the curriculum with reference to a local version of the curricular theme, one that develops over several months and becomes available for future discussions of related ideas. On several other days this year, the teachers and students have discussed the relative merits of individualism and collectivism in terms of taxes, asking whether "productive" members of a society should support "unproductive" ones through welfare and other social programs. When Mrs. Bailey refers to "taxes" at line 518, she is both referring back to what students have just said on January 25 and also presupposing earlier discussions in which the topics of taxes and welfare facilitated students' understanding of the individualism/collectivism theme.

Teachers' and students' local connection of the individualism/collectivism theme with the issue of welfare helps students reason about Rand's text and about the larger theme. At lines 523-525, Maurice offers a counter-argument to Rand: a society where individuals only look out for themselves would fail to care for the needy. Candace expands this argument by claiming that people cannot be self-sufficient, at lines 535-536. Candace and Maurice apply an emerging local 
argument to Rand's text here. Over the last week or two they have been discussing Aristotle and arguing that the individual should be subordinate to the state, at least in that the collective should help needy individuals through welfare and similar mechanisms. They build on this to argue against Rand's individualistic vision.

At lines 538-541, another student expands Candace’s point with reference to the division of labor. But the teacher steps in and defends Rand's position at lines 542-549. Her complaint about farm subsidies echoes discussions of welfare that have occurred in earlier classes, where more individualist authors had argued that the ideal society should not support unproductive people through welfare and subsidy programs. The students rise to the challenge, at line 555, when another student argues for the position that Maurice introduced earlier. This is exactly what the teachers want—-for students to defend themselves when their arguments are challenged. In this segment the students challenge the author, articulate an alternative position, and defend it against Rand and against the teacher. Their argument would of course require further development to be convincing. And their reliance on the single issue of welfare to understand the broader curricular theme would limit their understanding. Nonetheless, they are starting to develop local understandings and arguments in a promising way.

As the discussion proceeds on January 25, students continue to develop their own version of the arguments for collectivism and individualism. In the following excerpt, students refer back to earlier discussions of the same theme, thereby contributing to the local version of the theme that emerges over a month or two. (An "equality society" is the individualist one described by Rand).

855 T/B: Katie you got out on there on a $\underline{\text { limb }}$ (hh) by your (hh) self. why is it that you would not want to live in that soci- why 
it- why is it that you would like to live in equality society?

KAT: ${ }^{\circ}$ told you ${ }^{\circ}$

T/B: pardon?

860 KAT: ${ }^{\circ}$ you don't have to do anything you don't want to?ำ

T/B: you don't have to do anything you don't want to. ${ }^{\circ}$ okay. ${ }^{\circ}$

MRC: ${ }^{\circ}$ so she wouldn't have to come to school?

T/B: what happens in a society where you don't have to do anything you don't want to.

865 FST: (hh)

MRC: you] become beasts.

FST: $\quad]^{\circ}$ you become a cartoon ${ }^{\circ}$

CAN: I mean, who gonna help you when you become= FST: ${ }^{\circ}$ yeah ${ }^{\circ}$

870 CAN: =poor ho:meless=]

FST: $\quad$ Jyeah, who gonna help you?

CAN: =you be by yourself. you'll die girl. (hh)

[laughter from a few female students]

CAN: you get lonely.

875 FST: (hh)

CAN: you'll get lo:nely, we're human beings, human beings get lo:nely, hu:ngry.

As Mrs. Bailey did earlier, Katie has defended Rand's ideal society, in which each individual looks out for himself or herself. At line 866 Maurice begins a counter-argument, by referring 
back to the previous day's discussion of "beasts" or outcasts who refuse to contribute to society. This reference to beasts, a term Aristotle used to describe humans who live only for themselves, apart from society, begins to show the chain of events across which students develop their argument for a moderate collectivism. (The next section explores the January 24 discussion of “beasts.”) Candace and another student support Maurice’s position at lines 867-877, arguing that Katie herself might need others' support some day.

The students' argument here shows the emergence of a local cognitive pattern. Students and teachers recognize some of the classic arguments surrounding the collectivism/individualism debate. They engage with these arguments particularly around the more concrete questiondrawn from their own society and in some cases their own experience — of whether a society should have taxpayer-supported social welfare programs. In their discussion of Rand's Anthem we see students' emerging argument that fortunate members of a society should support those who need help. They condemn those like Rand who stand apart from the community and refuse to help others. This local cognitive model, developed in response to the curriculum, was available as they interpreted new texts. Having argued with Aristotle that a good society cannot afford "beasts" who support only themselves, the students were prepared to make a similar argument against Rand. Just as widely circulating categories of social identity were construed in particular ways in this classroom and became available to identify individuals (as, for example, “unproductive males”), teachers and students developed local cognitive categories for making sense of the curriculum. As we will see in the next section, the local category of "beast" or outcast became important for students' emerging understanding of the curricular theme and also for Maurice’s emerging social identity. 


\section{Interrelations between Identification and Learning}

From an "ontological” perspective all learning necessarily involves social identification (Lave, 1993, Packer, 2001, Wenger, 1998). If learning involves changing participation in social activities across time, learners become different kinds of people as they learn—because they shift their positions with respect to other people and/or with respect to socially defined activities. An apprentice craftsperson who learns a trade, for example, becomes a more trustworthy apprentice and perhaps a master while learning the relevant skills, and these shifts simultaneously involve both cognitive and identity development. In Mrs. Bailey and Mr. Smith’s classroom students also shifted their identities as they learned, as they became more competent participants in the activities of making and defending academic arguments.

Taking an ontological approach to learning, many have described more specific mechanisms through which social identification and learning can intertwine. Some argue, first, that students develop types of identities that are tied to curricular content, in the sense that one becomes a type of (for example) math student (Boaler, 2000; Greeno et al., 1998; Nasir, 2002; Walkerdine, 1988). Thinking of oneself as a "good" or "bad" math student can be a salient aspect of identity, and the development of such an identity may also influence how much a student learns. Second, some argue that identity-driven interactional patterns can shape opportunities for students in classroom activities, and that access to such activities can influence how much students learn. Gender, for instance, sometimes influences the course of classroom interactions (Brickhouse, 2001), and how a teacher deals with interactional challenges raised by gender can influence the subject matter that students learn (O’Connor, 2001). If boys refuse to let girls talk in science class, for instance, then the girls might not develop certain skills in science. This second mechanism can also involve students' own actions and motivation. 
Fordham and Ogbu (1986; Fordham, 1996; Ogbu, 1993), for instance, argue that some minority students adopt an "oppositional” identity as part of their alienation from mainstream school institutions. Such an oppositional identity leads students to disengage from prescribed subject matter, and thus they often learn less of the curriculum. Third, some argue that types of curricular content are correlated with types of identity (Lemke, 1990; Luke \& Freebody, 1997). Successful science students are often considered “nerds,” for example, and this identity can influence both their social and their academic lives.

All three of these mechanisms for describing interconnections between identity and learning (and likely others) can be plausibly defended. All three fall under the broad umbrella of ontological approaches to learning, describing how learning necessarily involves changes in identity. I am proposing a fourth mechanism which is parallel to these three, in that it also describes how identification and learning can interrelate. My mechanism is different, however, in that it describes much more specifically how particular concepts from the curriculum can intertwine with the social identification of particular students. I describe how specific themes and categories from the curriculum become resources for identifying students, and how categories for identifying students become resources for learning the curriculum. Categories of identity thus become part of the systems that make learning possible, while concepts from the curriculum become categories of identity that apply to students themselves. My argument follows the spirit of ontological approaches to learning, describing one way in which social identity and learning intertwine with each other. But I describe a more specific mechanism than the ones generally proposed. It is not just that students in Mrs. Bailey and Mr. Smith’s class get identified as increasingly competent participants in academic argument, nor just that their identities block or facilitate access to curricular content. I am arguing that one set of concepts 
plays a central role both in students' understandings of the curriculum and in their social identification of each other.

When the curriculum involves people as part of the subject matter-as in literature, history, social studies, and other content areas - the local cognitive models that teachers and students develop to understand the curriculum involve categories of identity. Discussion of the relation between an individual and society, for instance, could make available various categories of identity: dutiful citizens, loyal opposition, scathing critics, refusenik hermits and many others, depending on the texts read and the arguments introduced in class. In any classroom discussion of this theme, students and teachers will use some of these categories and not others. If they discuss the theme and the category of identity at length, they will generally develop local models of the curricular issue that borrow from but contextualize sociohistorical models and categories.

This article describes the intersection of the local cognitive models teachers and students develop as they learn the curriculum with the local models of identity that teachers and students develop as they socially identify one another. The curriculum becomes a resource for social identification, when students and teachers borrow categories of identity from their local cognitive models and insert them into the local models they use to identify students. And the social identities of students become a resource for learning the curriculum, when students and teachers borrow categories of identity from their local models of identity and use them in the local cognitive models that facilitate their understanding of the curriculum.

The development of simultaneously cognitive and identity-relevant categories is greatly facilitated by “experience-near” teaching. The analyses below focus on a particular type of classroom speech event: “participant examples” (Wortham, 1994). Social identification and learning can intertwine particularly deeply through participant examples and other experience- 
near pedagogical techniques. Participant examples include, as a character in the example, at least one teacher or student who is participating in the classroom discussion. Such examples double the roles played by those teachers and/or students, because they become characters in the example as well as participants in the classroom discussion. This doubling of roles makes participant examples rich sites for interactional positioning that might be relevant to social identification. Discussion of participants' hypothetical identities within the example can communicate things about the actual participants, as in a double entendre, when curricular categories get applied to identify students who participate in those examples. As I have described elsewhere (Wortham, 1994; 2001a), the simultaneous presupposition of both categories of identity and curricular categories in participant examples means that categories from one process can easily be used in the other. Students can get identified using categories from the curriculum, and/or curricular topics can get conceptualized using categories of identity. When students and teachers use themselves as a resource for understanding the curriculum, as in participant examples and other experience-near teaching, learning and social identification can deeply intertwine.

Consider the following participant example. For class on January 24 students had read selections from Aristotle’s Politics, in which he argues that "the state is by nature clearly prior to the individual since the whole is of necessity prior to the part.” As the teachers try to help students understand Aristotle's position, they focus on Aristotle's description of a "beast in the woods," a person who refuses to make the sacrifices necessary to live in society and who thus fails in Aristotle's view to become fully human. Maurice gets singled out as a hypothetical example of a beast in the woods.

T/B: I mean think of what- he's saying there. 
he’s saying if Maurice went out

and lived in the wo:ods (4.0) [some laughter]

300 FST: ${ }^{\circ}$ they're talking about you ${ }^{\circ}$

T/B: and never had any contact with the rest of us, he would be- uh- like an animal.

Subsequent discussion of this example has the potential to influence both Maurice's social identity and students' understandings of the curriculum.

Within the example, Mrs. Bailey identifies Maurice as "like an animal” and opposes him to "the rest of us." As we have seen, Maurice himself is in some respects an outcast from the rest of the class. The vocal girls try to exclude him from classroom discussion, by identifying him as an "unproductive boy." Continued discussion of him as a "beast in the woods" and as separate from "the rest of us" might facilitate these girls' identification of him as an outcast. If teachers and students use the concept of "beast" to describe Maurice as separate from the rest of the class, especially if they describe the hypothetical Maurice in ways that also apply to the real Maurice, discussion of the example could reinforce Maurice's real isolation in the classroom.

As described below, in subsequent discussion teachers and students do in fact use similar categories to identify Maurice and other boys as outcasts from the classroom and to construe Aristotle's idea of a "beast.” When teachers and students discuss Aristotle's argument that individuals apart from society cannot be fully human, they draw on the same categories that they use to identify male students like Maurice as unsuccessful members of the classroom "society." Thus categories like "beast” or "outcast” simultaneously get used to identify students socially and to construe the curricular theme. As students develop a local cognitive model of the curricular concept of "beast" and the relations between an individual and society, they borrow 
from that model to identify Maurice socially. And as they identify Maurice socially—drawing in part on local models of gender and other relevant aspects of Maurice's identity that they know about- they borrow from their conceptions of Maurice’s identity to construe the curriculum. Social identification and learning intertwine in this case because the same concept—a "beast in the woods," or an outcast—plays a central role both in the social identification of Maurice and in students learning the curriculum.

Because I am arguing that the intertwining of social identification and learning happens robustly through participant examples, my analyses focus on this type of speech event. I listened to the entire corpus of transcribed classes, and I identified all participant examples. I then determined how long each participant example remained the topic of discussion, and I transcribed all 23 participant examples that were discussed for more than two minutes. All these examples were analyzed using the discourse analytic techniques described below. Most of these 23 examples dealt with two particular themes from the curriculum, because most of the recordings were done during the months that the teachers organized the curriculum around these two themes. About half of the extended participant examples involved two students, Maurice and Tyisha, as characters. This fact, together with ethnographic observations, suggests that these two students' identities were particularly salient and contested over the year in the classroom.

This article describes how Maurice’s classroom identity emerged in part through discussion of classroom examples, and Wortham (2003) describes the emergence of Tyisha's classroom identity. Wortham (in press) describes each of these cases more extensively, tracing Tyisha and Maurice's identity development through all the extended participant examples they appeared in as well as analyzing other students' identity development and the classroom context across the academic year. Figure 1 represents the central participant examples that Tyisha and 
Maurice participated in. Each square represents an example, with the date of the classroom discussion, the central participant(s) and the curricular theme(s) discussed. The figure shows that both Tyisha and Maurice regularly became characters in participant examples, and it shows that two curricular themes recurred in these examples. Like Maurice, over the year Tyisha was increasingly identified as an outcast in the classroom—she became the one girl identified as unpromising. As described in Wortham (2003; in press) the curricular concept of outcast or "beast" was also used to identify her. The next section illustrates how teachers and students also drew on concepts from a second curricular theme to develop Maurice's identity as an outcast from the core group of vocal girls.

In order to learn more about Maurice and Tyisha's identities, beyond their roles in these participant examples, I went through the entire corpus and identified all explicit statements about these two students' identities—evaluations of their contributions, descriptions of their personalities and other relevant comments—-looking both for instances that confirmed and disconfirmed my interpretations (Erickson, 1992). The discourse analyses of how they were treated while discussing the participant examples, plus a summary of how they were explicitly identified by teachers and students over the year, support my claims about their emerging identities.

Discourse analyses were done according to the guidelines I have described elsewhere (Wortham, 1996; 2001b; Wortham \& Locher, 1996), following established methods of discourse analysis in linguistic anthropology (Silverstein, 1998), linguistics (Eggins \& Slade, 1997; Fairclough, 2003) and education (Castanheira, Crawford, Dixon, \& Green, 2000; Gee, 1999). This involves first finding all instances in a transcript of specific discursive cues that often presuppose things about speakers' or characters' identities. Metapragmatic verbs, or verbs of 
speaking, for instance, often presuppose something about the identity of the speaker being quoted (Vološinov, 1929/1973). When we say that someone “whined,” we presuppose something different about his or her identity than if we say s/he "said” something. After identifying all instances of several types of cues, the analyst looks for systematic patterns of cues that collectively presuppose a particular identity. Saying once that someone "whined," without any further cues, likely presupposes little about the person's identity. But saying a few times that he "whined” and "wheedled," and calling him a "brat,” more likely presupposes something about the speaker's position on this person's identity. The emergence of an identity depends on such a pattern of cues, and on the ratification of such a pattern by subsequent speakers (Sacks, Schegloff \& Jefferson, 1974). The patterns I describe were repeated on several occasions and picked up by other speakers. Any single instance may be plausibly interpreted in other ways, but the collection of instances support my interpretations.

\section{Maurice in the Middle}

As students and teachers discussed the relationship between individuals and society, they developed local models of curricular concepts like “outcast.” The vocal group of students rejected Rand’s individualistic perspective, condemning people who set themselves apart from society and refuse to aid others. They sometimes borrowed Aristotle’s concept of a "beast” to describe this sort of anti-social person. When they gave participant examples, they had an opportunity to apply concepts drawn from the curriculum to identify students who had roles in those examples. Teachers and students used the concept of "beast" to characterize Maurice (and Tyisha), and the teachers used Maurice's identity as an outcast to help students understand the curriculum. Later in the year, teachers and students built on the work they had done earlier with 
the concept of "beast" and the first curricular theme. As they discussed a second curricular theme—one that was related to and built on the first—-they continued to use curricular categories in ways that made Maurice’s hybrid identity uncomfortable.

The second curricular theme posited an unjust political order and asked whether an individual should remain loyal or resist. In part through participant examples, teachers and students developed an analogy between the social organization of the classroom and this theme. The teachers had power, and the vocal girls identified themselves as loyal to the teachers' agenda. Maurice's identity was affected in two ways by this analogy—one of them familiar. The idea of an established order and an individual outside of it kept Maurice's position as an outcast or a "beast" salient during their discussions of the second theme. The addition of "resistance" as a curricular category also allowed teachers and students to identify the other boys. While the individualism/collectivism theme allowed teachers and students to identify the vocal girls as central to the classroom "society" and Maurice as a "beast" or an "outcast" struggling to participate, the second theme allowed them to identify the teachers and the girls as the established political order and the boys as resisting that order—with Maurice caught in between the two groups. Discussion of the second curricular theme thus allowed the teachers and the girls to make Maurice's hybrid identity both salient and uncomfortable. The participant example discussed below shows how categories from the second curricular theme intertwined with the local categories used to identify Maurice.

The following example was discussed on May 10. The class has read Cicero's letter to Atticus, in which Cicero ponders what he should do about the tyranny of Caesar and the plot to overthrow him. Should he tell Caesar? Should he join the plotters? Or should he just keep quiet? In this respect, the text describes a three-part role structure in Rome: Caesar the tyrant, 
those plotting against him, and Cicero caught between the two. Mr. Smith gives a participant example to illustrate Cicero's dilemma.

T/S: Maurice let's give a good example, you'll love this. suppose this dictator, me. there was a plot going on.

150 and you found out about it. and you knew it was gonnait's existing (3.0) among the people you knew. would you tell me. (5.0)

MRC: you said they know about it.

T/S: the plotters, against me. they're planning to push me

155 down the stairs. [ and you know about it

STS: [hnhhahahaha

T/S: now we all know Maurice and I have ha(hh)d arguments all year. would you tell me about it.

MRC: well- I might but uh what if they- what if they found

160 out that I told you then they want to kill me. (5.0) so I'm putting myself in trouble to save you, and I'm not going to $\underline{\text { do }}$ it.

STS: hnh hahahaha

This example describes a role structure analogous to that in Rome: Mr. Smith the hypothetical tyrant, the conspirators plotting to push him down the stairs, and Maurice the potential informer stuck between the two.

Like most participant examples, this one may have implications for Maurice and Mr. Smith's own identities in the classroom—if characteristics attributed to participants' characters in 
the example also have implications for their own interactional positions. For instance, by asking whether Maurice would (hypothetically) side with him, against the student plotters, Mr. Smith may be raising a question relevant to Maurice’s own identity: is Maurice on the teachers' side or not? This could be an important question in this classroom, because of Maurice's liminal position. Maurice faces the delicate task of maintaining his status as a one of the boys, while also joining the girls and teachers in productive classroom discussion. In this context, when Mr. Smith asks Maurice whether he would side with him against the student "conspirators," the discussion might have implications for Maurice’s own in-between position-a position which is, as we will see, analogous to Cicero’s. We cannot conclude at this early point in the discussion that Maurice’s own identity is in fact relevant. But the possibility has been opened up, such that later discussion can presuppose and strengthen the parallel between Maurice’s hypothetical position as a potential informer caught between a tyrant and the plotters and his actual position as a boy caught between a desire to do well in school and his male peers' resistance.

Mr. Smith intends this example to help students learn about the facts of Cicero’s predicament and the larger theme of loyalty and resistance. In this and other texts, the class has been discussing the question of when citizens owe loyalty to their leaders and when they should resist unreasonable authority. By making Maurice a hypothetical Cicero, caught between loyalty to and resistance against the hypothetical tyrant, Mr. Smith hopes to engage students in reasoning about the choice between loyalty to and resistance against unjust authority. Even early in the discussion, local categories of identity and the local curricular theme run parallel. This example picks up the tension in Maurice's social identity, as a male student caught between his desire to be one of the boys and his desire to participate with the teachers and the girls in constructive classroom discussion. By giving an example that asks Maurice to choose between siding with 
the teacher or the plotters, Mr. Smith may be making salient Maurice’s year-long struggle between the two aspects of his classroom identity. As the discussion proceeds, the curricular theme becomes a resource for reinforcing Maurice’s social identity and Maurice’s identity becomes a resource for learning the curriculum — as Maurice's struggle over whether to side with the teachers helps students understand the predicament of potential informers.

Maurice's position in the classroom interaction—caught between the teachers and the resistant boys—-becomes increasingly salient and awkward. We begin to see this in the following segment:

T/S: well that was my next question, do you think Caesar was

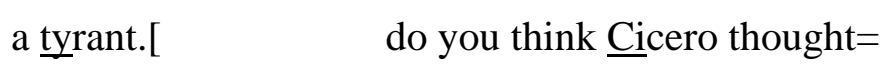

185 FST: $\quad$ [I don't think so.

T/S: =Caesar was a tyrant.

FST: no

MRC: yes

T/S: then what's his problem. if the man- you just told me

190 point blank [ that we could be pushed down stairs=

MRC: [so.

T/S: =and you wouldn't feel a thing about it. what's his big deal, if he believes Caesar is a tyrant, so what.

MRC: well- he- if u:h he [4 unintelligible syllables] that they're

195 making some kind of plot against him, but he doesn't want to get involved. He doesn't know if he should get involved, he could get himself in more trouble. since he's already [3 unintelligible syllables]= 
T/S: well if Caesar's a tyrant why shouldn't you get

involved. tyrants are generally dictatorial nasty people,

200 that prevent peo:ple from being at their ease.

When Mr. Smith says "you just told me point blank that we could be pushed down stairs and you wouldn't feel a thing about it" (lines 189-192), both the volume and tempo of his speech increase. He seems angry. This contrasts with his more light-hearted tone and laughter at line 157. Even though they are speaking about the example, Mr. Smith-the-teacher treats Maurice's choice not to tell him as a betrayal. (Mr. Smith uses "we” at line 190 because Mrs. Bailey has become another hypothetical tyrant in the example).

This starts to put the same sort of pressure on Maurice himself that was applied to Cicero and to Maurice in his hypothetical role as a potential informer. Maurice-the-student has begun to occupy Maurice-the-potential informer's role, as it is laid out in the example: he is getting caught between someone in power (the teacher) and others who oppose the teacher. In the classroom interaction itself, the other (oppositional) group includes male students who generally sit in the back of the classroom and refuse to participate. Note the emerging parallel between the events described in the text, the example, and the classroom itself. Cicero was caught in between those in power and those in opposition. In the hypothetical example, Maurice gets caught between the teachers and the students who oppose them. In the classroom, Maurice himself is caught between the teachers and the unresponsive male students.

In addition to reinforcing Maurice’s social identity, this parallel also has the potential to help students learn the curriculum. At lines 198-200, Mr. Smith makes an important point with respect to the curricular theme of loyalty and resistance. In the first segment, at lines 159-162, Maurice justified his decision not to warn the tyrant by citing concern for his own safety. At 
lines 198-200, Mr. Smith points out that, if Maurice is really dealing with a tyrant, he should join the resistance. The teacher is arguing that decisions about loyalty to those in power should not be made solely with respect to self-interest. Sometimes a citizen must act against those in power because of their immorality. As the students explore such arguments about Cicero’s predicament and about loyalty and resistance, later in the discussion, they use Maurice’s own identity as a resource.

In the excerpts above, Mr. Smith may simply have been teasing or play-acting to involve the students. Maurice himself may not really have been interactionally at risk. But Maurice's problems become more serious when several girls volunteer to tell the teachers about the plot. In this and subsequent segments the teachers skillfully use the example to involve students and to illuminate the subject matter. But the participant example also brings Maurice’s own identity into play.

T/S: gee you sound terribly confused Maurice. sort of like Cicero here.

T/B: what w- if you knew that they actually- you know there's a group of kids that are actually going to do: this

225 dastardly deed. and you know that there's going to be some reaction. what might you do th- and you kn- you know basically wh:ile you might not be- enamored totally of Mr. Smith or myself you- basically: don't wish that we were crippled for life or whatever, what might 230 you do that day. you know that's going to come- that this is all going to happen on Wednesday. what are you 
going to $\underline{\text { do }}$ that day.

CAN: I would try to warn you.

FSTs: right. I would $((*$ overlapping [comments *))

235
T/B:
[he's- he's not- he's not

going to warn us though.

T/S: no.

T/B: what- what are you going to do that day Maurice. (1.0)

MRC: stay away. [2 unintelligible syllables]

240 T/B: what are you going to do?

MRC: I'm going to stay away so I won't be- be:

T/B: so you're not going to come to school on Wednesday.

MRC: ${ }^{\circ} \mathrm{no}^{\circ}$

CAN: that way he's a coward.

245 FST: what would you do.

MRC: what would you do.

T/S: a coward.

CAN: yeah 'cause he's scared.

At lines 233-4, Candace and then other female students affiliate with the teachers, within the example. This adds another interactional group to the example: loyal subjects. When Candace, and then Mr. Smith, call Maurice a coward (at lines 244-248), Candace begins to speak as Candace-the-student and not just as a hypothetical Roman. She is not only elaborating the example here, but also picking on Maurice himself. This identifies another group in the classroom—the girls—who position themselves with respect to Maurice and the teachers. Like 
their characters in the example, in the classroom the girls affiliate with the teachers and exclude Maurice.

Thus the girls have intensified Maurice's predicament. Insofar as he wants to be a good student, Maurice might want to affiliate with Mr. Smith-the-tyrant—and thus, implicitly, with Mr. Smith-the-teacher. But to do so, he would have to affiliate with the teachers and the girls. This might damage his standing with the boys. Mr. Smith and Candace have thus put Maurice into a Cicero-like predicament, one that has implications for his social identity as a student and as a male, by mobilizing categories from the curriculum. The girls identify themselves as "loyal subjects” and they point out how Maurice has excluded himself from their and the teachers' group.

Like Maurice-the-potential informer, Maurice himself gets excluded by the other groups as he thinks about what to do. We can see this exclusion in a pattern of pronoun usage. For much of the remaining discussion (after line 244), other speakers exclude Maurice from the conversation, referring to him as he, whereas before they had referred to him as you. This shift from you to he establishes different organizations for the classroom interaction. Maurice himself started out participating with the teachers in the discussion of the example. However, immediately after Candace has said that she, unlike Maurice, would warn the teachers about the plot, the teachers and girls start to exclude Maurice. They could have continued to refer to him as you, as they do while discussing Mr. Smith and Candace as characters in the hypothetical example. The switch to he sends an interactional message: Maurice no longer belongs to the group that includes the teachers and girls in the classroom conversation. In both the example and the classroom, Maurice is caught on the outside. 
By the time the teachers address Maurice as you again, Mr. Smith speaks about Maurice’s interactional position in the past tense, as if it has already been settled.

T/S: you told us you wouldn't tell us anything.

FST: haha

FST: ${ }^{\circ}$ I wouldn't. ${ }^{\circ}$

T/S: you'd rather see our mangled bodies at the bottom of

365 the staircase.

MRC: I: told you I wouldn't be coming to school that day.

T/S: does that mean you're not part of the plot.

FST: yeah

MRC: I'd still be part of it. I- [if I

370 T/B: [if you- if you know about it=

T/S: if you know about it that's: an accomplice. you knew

about it. you could have stopped it. all you had to do is say-

it shouldn't be done, it's wrong.

Mr. Smith has apparently given up trying to entice Maurice to take his side. He accuses Maurice of wishing for the teachers' violent demise. At lines 364-5, his colorful comment might be taken as a joke. Maurice's tone at line 366 is nonetheless quite earnest. The example captures so well the ongoing tension between Maurice and the girls that it cannot be plausibly interpreted as merely a joke with no implications for Maurice’s identity.

Within the example, Maurice has made his decision, and this has consequences in the classroom interaction. After this segment, teachers and students consistently refer to Maurice as he for about six minutes. Maurice himself has been excluded from the teachers' and the girls' 
group. He can still be a member of the boys' group, but the other boys almost never participate in class. So in joining that group he gives up participating in classroom activity. All year long, Maurice has tried to maintain an identity both as a student who makes valuable contributions in class and as an adolescent male respected by his peers. In cases like this example, however, Mr. Smith and the girls make his balancing act particularly difficult, pressuring him to choose one or the other. They use categories from the curriculum to highlight the tension at the heart of Maurice's social identity in this classroom, and they force him to choose one side of himself over the other, at least for the moment.

In this participant example, then, categories from the curriculum get used to reinforce Maurice’s social identity. His responses to Mr. Smith’s challenge may have implications for Maurice’s identity as a "good" or "bad" student and as one of the boys—because the curricular theme of being loyal to or resisting authority maps neatly onto the identity-relevant categories of siding with the teachers or with the resistant boys. This one example, in itself, did not determine Maurice's identity. However, many other participant examples and events of social identification also reinforced Maurice’s identity as a male student caught between the “unpromising” boys and the "promising” girls who supported the teachers' agenda (Wortham, in press). Collectively, all these events established the tension between being a respected boy and a good student as a central aspect of Maurice's identity in this classroom. Although Maurice opted not to side with the teachers in the example about Cicero, in general he managed to be both a good student and a respected male. Nonetheless, all year long his experiences "in the middle" made salient the tensions between the two aspects of his hybrid identity.

At the same time as curricular categories of loyalty and resistance framed Maurice's identity, Maurice's identity — together with that of the teachers and the male and female 
students—helped students learn the curriculum. The teachers wanted students to learn about Cicero's predicament through Maurice's, and in fact students were able to characterize that predicament in terms of Maurice's. Later in the discussion teachers and students explicitly lay out the analogy between Maurice’s position in the classroom “society” and Cicero's position in Roman society. In the following segment, Mrs. Bailey is leading students through the first of ten questions that Cicero explicitly asks his friend Atticus in the text.

T/B: okay so now let's see how we can compare

455 Maurice's situation at this point to the options that Cicero is articulating or lining out for his friend Atticus. take the first one would you Gary. (4.0) just take the first one. read it and let's see what we can do with it. how does Maurice's situation compare with

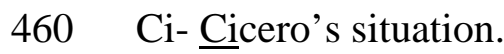

GAR: [reading] should a man continue to live in his own country under a dic- tatorship.

T/B: okay, what would that mean as far as Maurice.

CAN: shou- should he stay in the room even though Mr.

465 Smith's been a bad- a hard teacher.

Without hesitation here, Candace follows the teacher's lead and rephrases one of Cicero's questions in terms of the "Maurice in the middle" example. Other students are able to do this with the questions that follow, providing evidence that they understand the analogy.

Such analogical thinking between students' own experience and the issues raised in the text is central to the teachers' goal of having students engage with curricular themes. They want 
students to understand the themes with respect to their own experience, and then to use their own experience in formulating arguments about the themes. As they discuss Cicero's text, students begin to do this. Mrs. Bailey asks Ivory to read the second question from Cicero’s text.

475 IVR: [reading] should he do everything possible to overthrow the dictatorship. do the ends justify the means even if it place the state itself in danger.

T/B: okay. now what does that mean Ivory.

IVR: [reading] should he do everything- (6.0)

480 everything that- (5.0) [ should he do=

T/B: $\quad$ [Maurice.

IVR: =everything he c- he could to make Mr. S- Mr. Smith reconsider his a- assignment even if it means puttingthe class in danger.

485 T/B: o:kay. even if it means putting the class itself in danger, nicely done. okay now what are some of the things he could have done. (2.0)

IVR: um (2.0) he could have a meeting with Mr. Smith or something.

490 T/B: have a meeting with Mr. Smith. what would be the danger of talking to Mr. Smith about the impossibility of this assignment.

IVR: they could get into an argument. he can [3 unintelligible syllables] T/B: he gets into an argument. and what might result for the 
495 rest of the class. one of you just said state equals

class

STS: [unintelligible comments]

T/B: you don't like this. do twice as much. right? you've certainly’ve all run across that line at different

500 points. okay that might put you in danger. what also

might put you in danger. more extreme danger.

FST: he could just nail the whole class.

In this segment Ivory successfully uses the analogy between the text and the example, albeit with some help from the teacher. At line 482, for instance, she restates Cicero's second question in terms of the Maurice example. And at line 493 she begins to use what she knows about Maurice and Mr. Smith to extend her thinking about the issues raised in Cicero's text.

At line 502, we see a student continue this reasoning about the analogy. All the students know about Mr. Smith's “tyrannical” tendencies—he did in fact "nail the whole class” on occasion, by imposing harsh discipline and demanding large amounts of work. And this student knows that Maurice has challenged Mr. Smith all year, arguing against Mr. Smith both as a way of participating in class and as a way of maintaining his distance from the teachers. Knowledge about Maurice and Mr. Smith’s identities in the classroom, then, provides tools for students to think about Cicero's predicament and about the larger theme of loyalty and resistance. Students do not articulate a full argument about this theme during the "Maurice in the middle" class, but over the year they formulate such arguments about curricular themes in more sophisticated ways - as illustrated above in the January 25 discussion of Anthem. 
Thus categories of identity that have been established over the year in the classroom become resources as the students learn to participate in reasoned discussion of curricular themes, which was the teachers’ primary pedagogical goal. Students could have learned about the themes of loyalty/resistance and individualism/collectivism without reference to categories of identity. They certainly used other resources in learning about these themes. Nonetheless, in this case-especially as both social identification and learning got mediated through participant examples about Maurice and others — categories of identity did in fact become important resources as students developed local models of the curricular themes.

\section{Conclusions}

When categories of identity appear in participant examples like those described in this article, and in other classroom discussions, they can become resources both for social identification and for learning the curriculum. Students like Maurice can develop social identities in part as the curriculum provides categories of identity, as happened when teachers and students used “outcast” and the related model of social groups to help identity Maurice. Students can also learn the curriculum in part as the social identities of students like Maurice provide categories that can become tools for understanding curricular themes. Participant examples allow certain categories of identity—e.g., "beast” or "outcast," in Maurice’s case—-to contribute simultaneously to social identification and to learning. Students learn something about Cicero’s divided loyalties to both the powerful and the resistance, for instance, and they use this curricular knowledge to reinforce Maurice’s own hybrid identity. They also know something about the concept of resistance, from their knowledge of resistant males' identities in the classroom, and they use this knowledge to reason about the curricular theme of legitimate 
resistance. This intertwining of curricular themes and categories of identity happens as the same local categories of identity participate simultaneously in social identification and in learning. This sort of intertwining between local models of identity and local models of the curriculum represents one mechanism through which social identification and learning can partly constitute each other.

Because the intertwining between social identification and learning in Mrs. Bailey and Mr. Smith's classroom was accomplished in significant part through participant examples, it may seem that my account will not generalize to other contexts. This is both true and false. I discuss other types of speech events besides participant examples, like explicit descriptions of students' identities, and I show how these also played an important role in the social identification and learning the teachers and students accomplished. I claim, nonetheless, that participant examples play a key role in bridging the local social and cognitive models that are central to social identification and learning in this case. I acknowledge that many classrooms do not involve so many participant examples, or the analogies between the classroom and the curriculum that Mrs. Bailey and Mr. Smith established.

Even though my analysis relies heavily on participant examples, however, the sort of intertwining between social identification and learning that I describe likely occurs more widely. Participant examples are only one member of a widespread class of discursive and pedagogical tools. My analysis may generalize to a broad range of discourse which involves human subject matter and "personalization" as a rhetorical strategy. Other techniques besides participant examples can personalize subject matter, or bring it together with students' experiences and identities. Narratives of personal experience, for instance, can facilitate similar intertwining between categories used to describe particular students and categories used to describe the 
curriculum (Wortham, 2001b). Quoted speech can also resemble participant examples, when it allows a speaker to bring the words of a participant into an ongoing discussion of subject matter. Teachers commonly use devices like this in classroom discussion. Many language arts teachers, for instance, help students connect school reading to their own experience. Dyson (1989), McGinley and Kamberelis (1996), Wilhelm (1997) and others describe how teachers often help students connect their own experiences to the language arts and literature curriculum, so that students can use literature to explore themselves and their worlds. Edmiston and Enciso (2002) describe teachers and students creating “dramas” that involve students themselves in scenarios modeled on curricular topics. In these and many other cases, contemporary educators are creating classroom events that link students' experiences and identities with concepts and models from the curriculum. All these instances of personalization have the same potential I describe for participant examples, in which social identification and learning intertwine as categories from the subject matter overlap with categories used to frame students' identities.

The current study, together with the larger research project (Wortham, 2003; in press), suggests that the intertwining of local cognitive models and models of identity may be a robust mechanism of ontological learning, of the mutual constitution of social identification and learning. But future research will be needed to assess the extent to which personalizing discourse may help accomplish similar intertwining in other contexts. By looking for overlap or shared concepts between models of identity and local cognitive models of the curriculum, future research will be able to investigate whether this mechanism of identity/learning interaction occurs more widely. Related research on similar mechanisms of ontological learning suggests that future research may well find robust interconnections between social identification and 
learning (Brickhouse, 2001; Greeno et al., 1998; McGinley \& Kamberelis, 1996; O’Connor, 2001; Sfard, 1998, 2000).

The fact that social identification and learning can intertwine through personalizing discourse does not by itself recommend such intertwining as a pedagogical strategy. There are both risks and rewards to participant examples and similar pedagogical devices. Ideally, categories of identity drawn from students' own lives will enrich their understandings of the curriculum. Skillful teachers like Mrs. Bailey and Mr. Smith sometimes accomplish this. But categories that apply to students' own identities also carry risk. Maurice and some of the other students may have been distracted by the social identification done to Maurice in this classroom, and this might have interfered with their learning the curriculum. I do not recommend that teachers strive to eliminate social identification from their classrooms. This would be impossible, especially for curricular areas that involve human subject matter, and it would eliminate the useful pedagogical tool of personalization. Given the risks of distraction and the unfortunate social identification that can accompany personalizing discourse, however, these pedagogical techniques should be used with care. As we learn more about how social identification and learning intertwine, researchers and practitioners should keep in mind both the potential and the risks of doing both processes at once. 


\section{References}

Adler, M. (1982). The Paideia proposal. New York: Macmillan.

Agha, A. (2003). The social life of cultural value. Language and Communication, 23, 231-273.

Anderson, E. (1999). Code of the street. New York: W.W. Norton.

Bateson, G. (1972). Steps to an ecology of mind. New York: Ballantine.

Boaler, J. (2000). Mathematics from another world: Traditional communities and the alienation of learners. Journal of Mathematical Behavior, 18, 379-397.

Bourdieu, P. (1984). Distinction: A social critique of the judgement of taste. (R. Nice, Trans.). Cambridge, MA: Harvard University Press.

Brickhouse, N. (2001). Embodying science: A feminist perspective on learning. Journal of Research in Science Teaching, 38, 282-295.

Brown, L. \& Gilligan, C. (1992). Meeting at the crossroads. Cambridge, MA: Harvard University Press.

Castanheira, M.L., Crawford, T., Dixon, C.N., \& Green, J.L. (2000). Interactional ethnography: An approach to studying the social construction of literate practices. Linguistics and Education, 11, 353-400.

Cazden, C. (1988). Classroom discourse. Portsmouth, NH: Heinemann.

Cazden, C., John, V. \& Hymes, D. (Eds.). (1972). Functions of language in the classroom. New York: Teachers College Press.

Cole, M. (1996). Cultural psychology. Cambridge, MA: Harvard University Press.

Dreier, O. (2000). Psychotherapy in clients’ trajectories across contexts. In C. Mattingly \& L. Garro (Eds.), Narrative and at he cultural construction of illness and healing (pp. 237258). Berkeley: University of California Press. 
Dreier, O. (2003). Learning in personal trajectories of participation. In N. Stevenson, H. L. Radtke, R. Jorna, \& S. Henderikus (Eds.), Theoretical psychology: Critical contributions (pp. 20-29). Toronto: Captus Press.

Dyson, A. (1989). Multiple worlds of child writers. New York: Teachers College Press.

Edmiston, B., \& Enciso, P. (2002). Reflections and refractions of meaning: Dialogic approaches to classroom drama and reading. In J. Flood, D. Lapp, J. Squire, \& J. Jensen (Eds.). Handbook of research on teaching the English language arts (pp. 868-880). Mahwah, NJ: Lawrence Erlbaum.

Eggins, S., \& Slade, D (1997). Analyzing casual conversation. London, New York: Cassell. Erickson, F. (1992). The interface between ethnography and microanalysis. In M. LeCompte, W. Millroy, J. Preissle (Eds.), The handbook of qualitative research in education. San Diego: Academic Press.

Fairclough, N. (2003). Analysing discourse: Textual analysis for social research. New York: Taylor \& Francis, Inc.

Ferguson, A. (2000). Bad boys. Ann Arbor, MI: University of Michigan Press.

Foley, D. (1996). The silent Indian as a cultural production. In B. Levinson, D. Foley, \& D. Holland (Eds.). The cultural production of the educated person (pp. 79-91). Albany: State University of New York Press.

Fordham, S. (1996). Blacked out. Chicago, IL: University of Chicago Press.

Fordham, S., \& Ogbu, J. (1986). Black students and school success: Coping with the "burden of acting white.” Urban Review, 18, 176-206.

Gadsden, V., Wortham, S., Turner, H. (2003). Situated identities of young, African American fathers in low-income urban settings. Family Court Review, 41, 381-399. 
Gee, J. P. (1999). An introduction to discourse analysis: Theory and method. London; New York: Routledge.

Goffman, E. (1974). Frame analysis. New York: Harper and Row.

Goodwin, C. (1995). Seeing in depth. Social Studies of Science, 25, 237-274.

Greeno, J. (1997). On claims that answer the wrong questions. Educational Researcher, 26, 5-17.

Greeno, J.G., \& Middle School Mathematics through Applications Project Group (1998). The situativity of knowing, learning, and research. American Psychologist, 53, 5-26.

Honora, D. (2003). Urban African American adolescents and school identification. Urban Education, 38, 58-76.

Holland, D., \& Eisenhart, M. (1990). Educated in romance. Chicago, IL: University of Chicago Press.

Hutchins, E. (1995). Cognition in the wild. Cambridge, MA: MIT Press.

Jordan, W., \& Cooper, R. (2003). High school reform and black male students: Limits and possibilities of policy and practice. Urban Education 38, 196-216.

Kamberelis, G., \& Scott, K. (1992). Other people’s voices. Linguistics \& Education, 4, 359-403.

Latour, B. (1993). We have never been modern. (C. Porter, Trans.). Cambridge, MA: Harvard University Press.

Lave, J. (1988). Cognition in practice. New York: Cambridge University Press.

Lave, J. (1993). The practice of learning. In S. Chaiklin \& J. Lave (Eds.), Understanding practice (pp. 3-34). NY: Cambridge University. 
Leinhardt, G. (2000). Lessons on teaching and learning in history from Paul's pen. In P. Stearns, P. Seixas, \& S. Wineburg, Knowing, teaching and learning history (pp. 223-245). New York: New York University Press.

Lemke, J. (1990). Talking science. Norwood, NJ: Ablex.

Lemke, J. (2000). Across the scales of time. Mind, Culture \& Activity, 7, 273-290.

Luke, A., \& Freebody, P. (1997). Shaping the social practices of reading. In S. Muspratt, A. Luke, \& P. Freebody (Eds.), Constructing critical literacies: Teaching and learning textual practice. Cresskill, NJ: Hampton Press.

McDermott, R. (1997). Achieving school failure: 1972-1997. In G. Spindler (Ed.), Education and cultural process: Anthropological approaches (3 ${ }^{\text {rd }}$ ed., pp. 110-135). Prospect Heights, IL: Waveland Press.

McGinley, W., \& Kamberelis, G. (1996). Maniac Magee and Ragtime Tumpie: Children negotiating self and world through reading and writing. Research in the Teaching of English, 30, 75-113.

Mehan, H., Villanueva, I., Hubbard, L., Lintz, A., \& Okamoto, D. (1996). Constructing school success. New York: Cambridge University Press.

Moje, E. (2000). To be part of the story. Teachers College Record, 102, 651-690.

Nasir, N. (2002). Identity, goals, and learning: Mathematics in cultural practice. Mathematical Thinking and Learning, 4, 213-24.

Newkirk, T. (2002). Misreading masculinity. Portsmouth, NH: Heinemann.

Nightingale, C. (1993). On the edge: A history of poor black children and their American dreams. New York: Basic Books. 
O’Connor, M. (2001). Can any fraction be turned into a decimal? Educational Studies in Mathematics, 46, 143-185.

Ogbu, J. (1993). Frameworks-variability in minority school performance. In E. Jacob and C. Jordan, (Eds.), Minority education: Anthropological perspectives (pp. 83-111). Norwood, NJ: Ablex Publishing Corporation.

Packer, M. (2001). Changing classes. New York: Cambridge University Press.

Pottorff, D., Phelps-Zientarski, D., \& Skovera, M. (1996). Gender perception of elementary and middle school students about literacy at school and at home. Journal of Research and Development in Education, 29, 203-211.

Rex, L. \& McEachen, D. (1999). “If anything is odd, inappropriate, confusing, or boring, it’s probably important”: The emergence of inclusive academic literacy through English classroom discussion practices. Research in the Teaching of English, 34, 65-129.

Rogoff, B. (1998). Cognition as a collaborative process. In D. Kuhn \& R. Siegler (Eds.), Handbook of child psychology, vol. 2: Cognition, perception and learning (pp. 679-744). New York: Wiley.

Sacks, H., Schegloff, E., \& Jefferson, G. (1974). A simplest systematics for the organization of turn-taking in conversation. Language, 50, 696-735.

Sadker, M., \& Sadker, D. (1995). Failing at fairness: How America's schools cheat girls. New York: Scribner.

Sfard, A. (1998). On two metaphors for learning and the dangers of choosing just one. Educational Researcher, 27(2), 4-14.

Sfard, A. (2000). Steering (dis)course between metaphors and rigor: Using focal analysis to investigate an emergence. Journal for Research in Mathematics Education, 31, 296-327. 
Silverstein, M. (1992). The indeterminacy of contextualization: When is enough enough? In A. DiLuzio \& P. Auer (Eds.), The contextualization of language (pp. 55-75). Amsterdam: John Benjamins.

Silverstein, M. (1998). Contemporary transformations of local linguistic communities. Review of Anthropology, 27, 401-426.

Sinatra, G., Beck, I., \& McKeown, M. (1992). A longitudinal characterization of young students' knowledge of their country’s government. American Educational Research Journal, 29, 633-661.

Spencer, M. (1999). Social and cultural influences on school adjustment. Educational Psychologist, 34, 43-57.

Sum, A., \& Harrington, P. (2003). The hidden crisis in the high school dropout problems of young adults in the U.S.: Recent trends in overall school dropout rates and gender differences in dropout behavior. Boston: Center for Labor Market Studies, Northeastern University. Retrieved May 21, 2003, from http://www.nupr.nev.edu/5-03/dropout.html. Urban, G. (2001). Metaculture. Minneapolis, MN: University of Minnesota Press.

Varenne, H. \& McDermott, R. (1998). Successful failure. Boulder, CO: Westview Press. Vološinov, V. (1929/1973). Marxism and the philosophy of language (L. Matejka \& I. Titunik, translators). Cambridge, MA: Harvard University.

Vygotsky, L. (1934/1987). Thought and language (A. Kozulin, Trans.). Cambridge, MA: MIT Press.

Walkerdine, V. (1988) The mastery of reason: Cognitive development and the production of rationality. London; New York: Routledge. 
Wenger, E. (1998). Communities of practice: Learning, meaning and identity. New York: Cambridge University Press.

Wertsch, J. (1998). Mind as action. New York: Oxford University Press.

Wilhelm, J. (1997). You gotta BE the book. New York: Teachers College Press.

Willis, P. (2001). “Takin’ the piss.” In D. Holland \& J. Lave (Eds.), History in person: Enduring struggles, contentious practice, intimate identities. Santa Fe, NM: School of American Research Press.

Wineburg, S. (2001). Historical thinking and other unnatural acts. Philadelphia: Temple University Press.

Wortham, S. (1994). Acting out participant examples in the classroom. Philadelphia: John Benjamins Publishers.

Wortham, S. (1995). Experiencing the great books. Mind, Culture, and Activity, 2, 67-80.

Wortham, S. (1996). Deictic mapping. Journal of Pragmatics, 25, 331-348.

Wortham, S. (2001a). Interactionally situated cognition: A classroom example. Cognitive Science, 25, 37-66.

Wortham, S. (2001b). Narratives in Action. New York: Teachers College Press.

Wortham, S. (2001c). Gender and school success in the Latino diaspora. In S. Wortham, E, Murillo, \& E. Hamann (Eds.), Education in the new Latino diaspora: Policy and the politics of identity (pp. 117-141). Westport, CT: Ablex.

Wortham, S. (2003). Curriculum as a resource for the development of social identity. Sociology of Education, 76, 229-247.

Wortham, S. (in press). Learning identity. New York: Cambridge University Press. 
Wortham, S., \& Locher, M. (1996). Voicing on the news: An analytic technique for studying media bias. Text, 16, 557-585 


\section{Appendix A: Transcription Conventions}

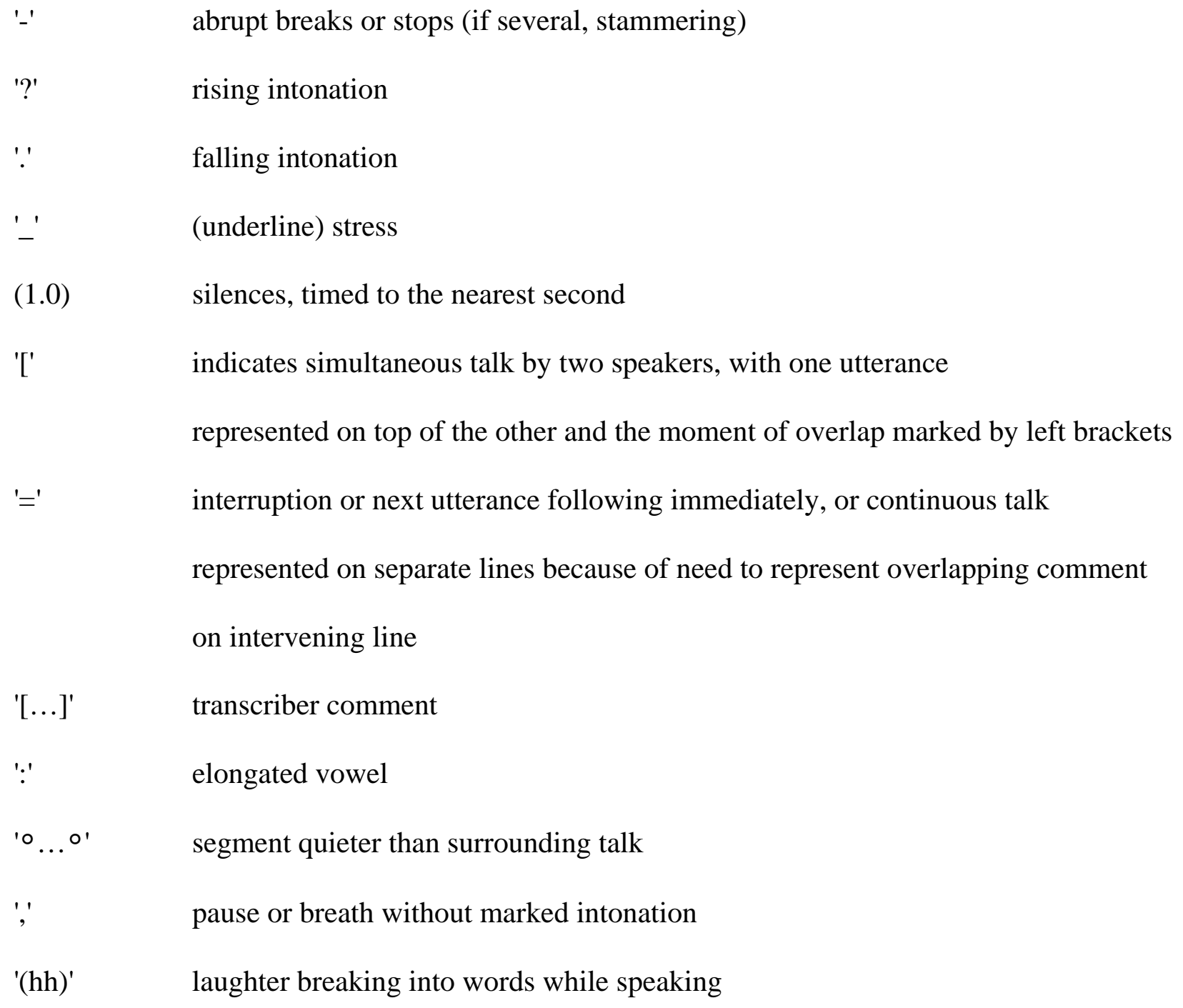




\section{Appendix B: Abbreviations for Participant Pseudonyms}

$\begin{array}{ll}\text { CAN } & \text { Candace } \\ \text { FST } & \text { Female Student } \\ \text { GAR } & \text { Gary } \\ \text { IVR } & \text { Ivory } \\ \text { JAS } & \text { Jasmine } \\ \text { KAT } & \text { Katie } \\ \text { KTN } & \text { Katina } \\ \text { MRC } & \text { Maurice } \\ \text { STS } & \text { Students } \\ \text { T/B } & \text { Mrs. Bailey } \\ \text { T/S } & \text { Mr. Smith }\end{array}$

TYI Tyisha 


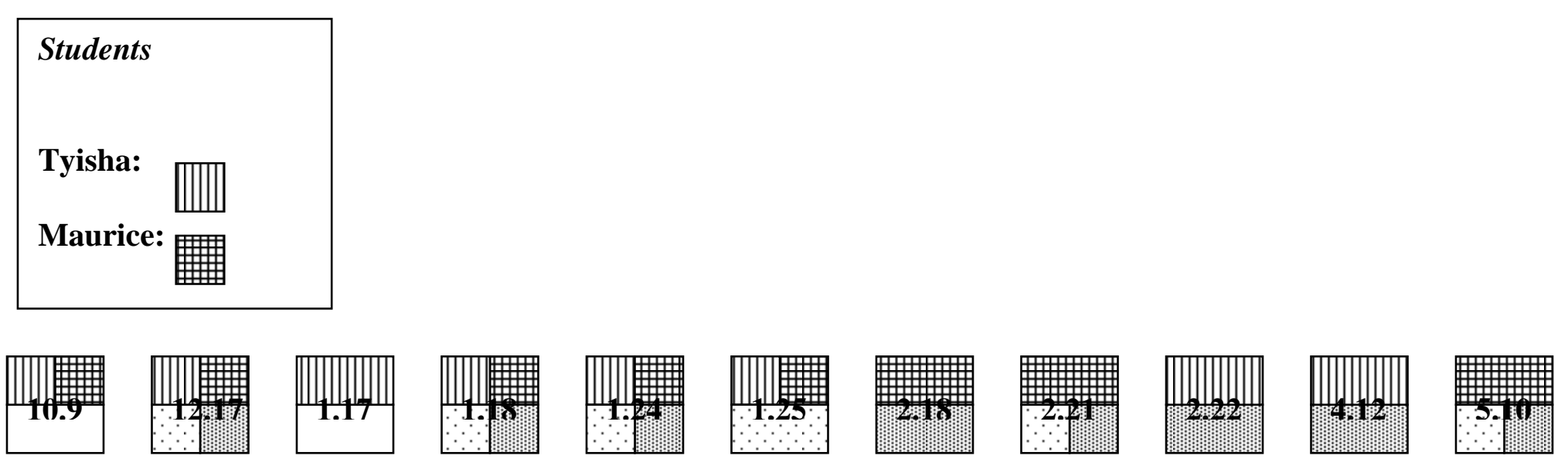

\section{Themes}

Theme 1: Individual vs. Society

Theme 2: Loyalty and Resistance

Each square represents an extended participant example and the date on which it was discussed.

Figure 1. Extended participant examples involving Tyisha and Maurice. 